\title{
Javanese Varieties in Pringsewu Regency and Their Origins
}

\author{
Suprayogi \\ suprayogi@teknokrat.ac.id \\ Universitas Teknokrat Indonesia
}

\begin{abstract}
It has been an interesting discussion on how certain language is spoken in the area far from its center. This paper is aimed at describing the Javanese language varieties in Pringsewu regency of Lampung province, locating the area where these varieties are spoken, and revealing the history why these varieties appear in the areas. By employing dialectology study using isogloss bundles and dialectometry, it was found that in the 18 Javanese observation locations (OL), the Javanese varieties are mostly indicated by both lexical and sound variation, and these varieties are classified in less than $30 \%$ lexical difference. There are some areas using Banyumas dialect with its distinctive features and also varieties that reflect standard Javanese. The Javanese varieties in this area are spoken as the first language by the informants. The varieties are derived from the migrants coming several parts in Java Island with different periods and motifs of arrival.
\end{abstract}

Keywords: Dialectology, Javanese, history, variation

\section{Introduction}

Javanese is a language that are dominantly spoken by people inhabiting Java Island where the island becomes the center of the language as well. Due to the dynamic life of its speakers, Javanese language is spread to wider areas following where the Javanese people migrate. Ethnologue (2018) has noted that in 2011 the number of Javanese speakers reaches 95,200,000 spreading across Central Java province, Yogyakarta Province, East Java Province, Lampung province and some areas in Borneo, and even reaching across nation border in Suriname and Caledonia. These data show that the existence of Javanese is remarkable since until now this language is fluently spoken though has been brought since long time ago in different areas across the globe. Thus, it is not surprising that this language stays in the 13th position of the most spoken language in the world according to SIL (Summer Institute of Linguistics and in $1^{\text {st }}$ in Indonesia (Lauder, 2007).

In the era when Dutch ruled Java, Java Island was considered overpopulated that would lead to social and economical problems. Thus, transmigration was initiated by Dutch under ethiesche politiek (education, transmigration and irrigation). Many of Javanese were brought to other Dutch colonies such as in Suriname in 1890, New Caledonia around 20th century (Wedhawati, 2006) they were sent to be labor in plantation. Not only brought to other countries, Javanese people were also sent to other islands within Indonesia. This program is called Kolonisasi or migrating people as a measure solving overpopulation. One of the targeted areas is Gedongtataan region in Lampung Province.

The transmigration program in Gedongtataan was expanded to the neighboring areas, one of them headed to the west to Pringsewu area. Therefore, it is predicted that there are many Javanese people living there in Pringsewu. The name "Pringsewu" also indicates Javanese influence. Pring is the Javanese word for bamboo, meanwhile Sewu means thousand. This name according to toponymy perspective is derived from the first area where Javanese convert bamboo forest into residential area. 


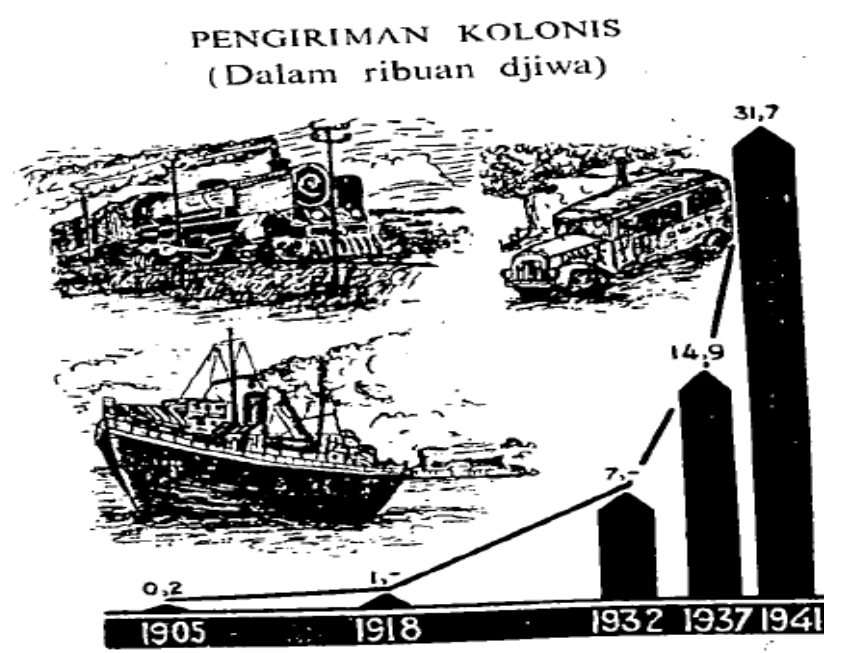

Picture 1. The illustration of transmigrants' deployment

Due to great number of Javanese people in this area, this research aims to investigate Javanese language distribution and the varieties. The investigation on where the Javanese language is spoken in this area and how the varieties look like are considered important for the language mapping program that later can have pedagogical and social implication. The dialectology research on Javanese varieties has even been conducted in provincial scale by Zawarnis (2009). However, the areas that have been map are only two out of 133 villages in Pringsewu. Therefore, this research could significantly portray the brighter and wider map of the Javanese variation in this area.

\section{Method}

This research employed both qualitative and quantitative method. The qualitative method was used to describe the lexical and phonological variation of Javanese language meanwhile the quantitative method was used to measure the distance of variation between two neighboring lects or varieties. This research was conducted in Pringsewu Regency in Lampung Province, Indonesia. Pringsewu is one of 15 regencies in Lampung, and it consists of 131 administrative villages (BPS Pringsewu, 2015). These villages are distributed in 9 sub districts namely Kecamatan Pagelaran, Kecamatan Pagelaran Utara, Kecamatan Pringsewu, Kecamatan Ambarawa, Kecamatan Pardasuka, Kecamatan Sukoharjo, Kecamatan Banyumas, Kecamatan Adiluwih, dan Kecamatan Gadingrejo. Geographically, this land-locked region is located at $104^{\circ} 48^{\prime}-105^{\circ} 08^{\prime}$ Eastern Longitude $5^{\circ} 12^{\prime}-5^{\circ} 33^{\prime}$ Southern Latitude. It is low land area with large paddy plantation, as well as coffee and pepper. Demographically, Pringsewu is inhabited by 383,101 residents based on the demographic census in 2014.

For the specific area to observe, there were 18 Javanese villages were selected as the observation location (OL). The villages were chosen based on even distribution and the oldvillage consideration. These 18 villages are listed in the following table.

\begin{tabular}{|c|l|c|l|}
\hline No & Subdistrict & $\begin{array}{c}\text { Number } \\
\text { of Village }\end{array}$ & \multicolumn{1}{|c|}{ Name of Village } \\
\hline 1 & Pagelaran & 3 & Desa Bumiratu, Desa Candiretno, Desa Pujiharjo. \\
\hline 2 & $\begin{array}{l}\text { Pagelaran } \\
\text { Utara }\end{array}$ & 2 & Desa Margosari, Desa Giri Tunggal. \\
\hline 3 & Pringsewu & 2 & Desa Waluyojati, Desa Bumi Arum. \\
\hline 4 & Pardasuka & 0 & (Mostly Lampung-speaking areas) \\
\hline 5 & Ambarawa & 2 & Desa Kresnomulyo, Desa Ambarawa. \\
\hline
\end{tabular}




\begin{tabular}{|c|l|c|l|}
\hline 6 & Sukoharjo & 2 & Desa Pandansari, Desa Keputran, \\
\hline 7 & Adiluwih & 2 & Desa Adiluwih, Desa Totokerto, \\
\hline 8 & Gadingrejo & 4 & $\begin{array}{l}\text { Desa Wonodadi, Desa Mataram, Desa Wates, Desa } \\
\text { Gadingrejo Timur }\end{array}$ \\
\hline 9 & Banyumas & 1 & Desa Banyuwangi \\
\hline \multicolumn{2}{|l}{ Total } & $\mathbf{1 8}$ &
\end{tabular}

Table 1. Observation Location

To investigate what language are spoken, the dialectology study was conducted. Dialectology is the study to describe language variation in particular area (Chambers and Trudgill, 2007). In this context, the variation refers to geographical variation, not social variation. This field research was conducted through interview and observation. The instrument of this research was adopted from Kuesioner Kosakata Swadesh dan Kata Budaya Dasar from Kementerian Pendidikan Nasional or Ministry of National Education (2013). The questionnaire consists of three parts. The first is village profile, the second part is the informant's profile, and the third part is the wordlist. Swadesh list consisting of 200 words was taken. Swadesh list consists of basic words believed to be exist in any language in the world and it is common to be used for language variation research. Furthermore, for the informant, the criteria are 1) Born in the village of OL, 2) fluent to speak Javanese, 3) has maximum senior high school degree. One informant in each Observation Location was selected, so there are 18 informants in total.

To measure the degree or distance of variation between neighboring lects, dialectometry analysis by Seguy was used. It is the measurement of dialect differences, i.e linguistic differences whose distribution is determined primarily by geography (Nerbonne and Kretzschmar, 2003) and range of dialectometry result by Lauder (1990 in Ayatrohaedi, 2002) was applied. The following is the formula to calculate dialectometry as proposed by Seguy.

$$
\frac{\mathrm{s} \mathrm{x} 100}{\mathrm{n}}=\mathrm{d} \%
$$

The $s$ in the formula refers to the number of lexical difference between two areas meanwhile $n$ refers to the number of words listed as the instrument, and $d$ is the dialectometry or the degree of difference represented in percentage. The ranges of percentage of dialectometry are as follows: $>70 \%$ means both lects are different in language, $51-70 \%$ means both lects are different in dialect, $41-50 \%$ means different in subdialect, and 31-40\% means different in speech, and $<30 \%$ is considered not different in lect.

\section{Findings and Discussion}

\section{Dialectometry Calculation}

The observation locations (OL) are spread from the west to the east as well as from the north to the south. The dialectometry calculation showed that the dialectometry ranges from $4 \%-14 \%$ for lexical differences, which means that the Javanese areas have low lexical differences and they are classified as similar language/no different language lexically. It means that among the varieties, they are still mutually intelligible. The following table is the detail percentages of each Observation Location (OL) pair.

\begin{tabular}{|c|c|c|}
\hline OL Pair & D & \% \\
\hline Wonodadi - GadingrejoTimur & 18 & $9.0 \%$ \\
\hline Wonodadi - Wates & 18 & $9.0 \%$ \\
\hline Wonodadi - Ambarawa & 15 & $7.5 \%$ \\
\hline Gadingrejo Timur - Srikaton & 12 & $6.0 \%$ \\
\hline
\end{tabular}

\begin{tabular}{|c|r|c|}
\hline OL Pair & \multicolumn{1}{|c|}{ D } & \multicolumn{1}{|c|}{$\%$} \\
\hline Wates - Keputran & 17 & $8.5 \%$ \\
\hline Wates - Bumiarum & 19 & $9.5 \%$ \\
\hline Ambarawa - Waluyojati & 19 & $9.5 \%$ \\
\hline Ambarawa - Kresnomulyo & 8 & $4.0 \%$ \\
\hline
\end{tabular}




\begin{tabular}{|c|r|r|}
\hline Gadingrejo Timur -Pandansari & 16 & $8.0 \%$ \\
\hline Gadingrejo Timur - Mataram & 19 & $9.5 \%$ \\
\hline Gadingrejo Timur - Wates & 12 & $6.0 \%$ \\
\hline Srikaton - Totokarto & 8 & $4.0 \%$ \\
\hline Srikaton - Pandansari & 20 & $10.0 \%$ \\
\hline Srikaton - Margosari & 14 & $7.0 \%$ \\
\hline Totokarto - Pandansari & 18 & $9.0 \%$ \\
\hline Totokarto - Keputran & 18 & $9.0 \%$ \\
\hline Pandansari - Mataram & 28 & $14.0 \%$ \\
\hline Pandansari - Keputran & 24 & $12.0 \%$ \\
\hline Mataram - Wates & 21 & $10.5 \%$ \\
\hline Mataram - Keputran & 21 & $10.5 \%$ \\
\hline Wates - Ambarawa & 20 & $10.0 \%$ \\
\hline
\end{tabular}

Table 2. Dialectometry of Each OL Pair

\begin{tabular}{|c|r|r|}
\hline Bumiarum - Waluyojati & 16 & $8.0 \%$ \\
\hline Bumiarum - Pamenang & 14 & $7.0 \%$ \\
\hline Waluyojati - Kresnomulyo & 9 & $4.5 \%$ \\
\hline Waluyojati - Pamenang & 15 & $7.5 \%$ \\
\hline Waluyojati - Candiretno & 13 & $6.5 \%$ \\
\hline Kresnomulyo - Candiretno & 10 & $5.0 \%$ \\
\hline Kresnomulyo - Pujiharjo & 8 & $4.0 \%$ \\
\hline Pamenang - Candiretno & 14 & $7.0 \%$ \\
\hline Pamenang - Pujiharjo & 17 & $8.5 \%$ \\
\hline Candiretno - Pujiharjo & 12 & $6.0 \%$ \\
\hline Banyuwangi - Giritunggal & 16 & $8.0 \%$ \\
\hline Banyuwangi - Margosari & 15 & $7.5 \%$ \\
\hline Giritunggal - Margosari & 8 & $4.0 \%$ \\
\hline
\end{tabular}

Among 200 words in Swadesh list, the highest degree of differences occurred between Desa Mataram and Desa Pandansari, which is 28 lexicon or 14\%, meanwhile the lowest lexical differences are in Giri Tunggal - Margosari and Kresnomulyo - Ambarawa, which are $4 \%$ or 8 words difference. It means that from 200 words of Swadesh, there are around $172-192$ words that are similarly used by the Javanese speakers in this 18 areas. This lexical difference might occur due to geographical location and different world view between people in Desa Mataram and Desa Pandansari.

\section{Lexical Variations}

The lexical variation is not densed in the areas as they consists of homogenous ethnic group. However, two until five lexical variation from the same gloss can be found in the areas. Here are the examples of some lexical variations based in etymon. Two etymon variation appears in the gloss "TO BURN" which are [obon] and [bakar]. Three etymon variation appears in the gloss "DOG" which are [asu], [səgawon] and [kere?]. Four etymon variation appears in the gloss "CLOUD" which are [mendUn], [awan], [kabUt], [lamUk]. The highest etymon variation is five, it appears in the gloss "LAKE". The lexical variations are [rows], [kədUn], [danaw], [mbUy], [təlogo]. Based on the interview to the informants, concept of "LAKE" is hard to describe as some of them find it hard to find the appropriate concept and things in their environment. Thus some of them use [rowo] that actually means swamp, [kədUn] that means the deepest part in a river, [mbUn] that means pond and [təlogs] that means lake.

There are also some glosses which are consistently used in some regions but are not used in other regions. It can be said that these glosses considered as the typical glosses in the areas. The first one is the gloss "CLOUD" which is expressed by the etymon [lamUk?] in Bumiarum, Wonodadi, Waluyojati and Pamenang, meanwhile most of the Javanese areas uses the etymon [mendUn]. The second is the gloss "FATHER". Pamenang, Wonodadi, and Bumiarum used the etymon [rama] meanwhile other areas used [bapa?]. The third one is in the gloss "NOSE" where Pamenang, Candiretno, Banyumas, Wonodadi, Bumiarum, Waluyojati used the etymon [cunur] meanwhile in other areas, [IrUn] is used extensively. The fourth one is how people in Pamenang, Candiretno, Banyumas, Wonodadi, Bumiarum, Waluyojati used [ñon] refering to "I" unlike the other regions which used [aku]. The last typical etymon is [beda?] to refer to "DIFFERENT", meanwhile other regions used etymon [liyo]. These examples mean that these 6 observation locations have shown consistent used of certain lexicon. For easier explanation, these 6 areas later in this research are called as Area $A$, and the rest of observation location is then called Area B, which means villages included in Area $B$ reflect similar features in lexicon and phonology, but rather different from village in area $A$. 


\section{Phonological Variations}

Besides lexical variation, phonological variation also appeared in Pringsewu region. Most of them occurred between Area A and Area B. Phonological variations found in this research is the variation based on vowel sound correspondence. The first one is when [0] in Javanese Area $B$ corresponds to [a] in Javanese Area A. It happened in some following glosses.

\begin{tabular}{|c|c|c|c|}
\hline No & AREA B [0] & AREA A [a] & Gloss \\
\hline 1 & [kono] & [kana?] & THERE \\
\hline 2 & [təko] & [təka?], [təka] & TO COME \\
\hline 3 & [ombo] & [amba?] & WIDE \\
\hline 4 & [mots] & [mata] & EYES \\
\hline 5 & [sopo] & [sapa], [sapa?] & WHO \\
\hline 6 & [tuo] & [tua], [tua?] & $O L D$ \\
\hline 7 & [tums] & [tuma] & KUTU \\
\hline 8 & [tibo] & [tiba?] & TO FALL \\
\hline 9 & [эро] & [apa], [apa?] & WHAT \\
\hline
\end{tabular}

Table 3. Sound correspondence

This sound correspondence occurred in many glosses with same pattern and it considered significantly consistent. It happened in the gloss end with vowel sounds [0] and [a] or [a] with glottal end, so it becomes [a?]. The correspondence happen in almost twosyllable word. If the two syllable word consists of two same vowel sounds [0] and [0], it will "change", or in Area A is [a] and [a]. Furthermore, if the two word syllable has different vowel sound and the last sound is [0] sound, the sound in Area A is [a].

Another sound correspondence occurred in both areas in the allophone $[\mathrm{e}]$ and $[\varepsilon]$, allophone [U] and [u], and allophone [I] and [i]. The sound [e] in Area B corresponds to the sound $[\varepsilon]$ and $[\mathrm{e}]$ in Area A, the sound $[\mathrm{U}]$ in Area B correspond to the sound $[\mathrm{U}]$ and $[\mathrm{u}]$ in Area A, and the sound [I] correspond to the sound [I] and [i] in Area A. In this study, this sound correspondence can be seen in the gloss "YOU". In Area B, it is expressed in [koe] meanwhile in Area A there are [koe] and [kəع]. In the gloss "YOU", Area B has [səyene] meanwhile Area A has [səyene] and [sə⿹⿻弋一㇂㇒] . In the gloss "TAIL", people in Area B usually say [bUntUt], meanwhile people in Area B say [bUntUt], and [buntut]. The [i] and [I] sound appear in the gloss "SKY". People in Area B say it using [layIt] and [layit].

These sound $[\mathrm{e}] \sim[\varepsilon],[\mathrm{U}] \sim[\mathrm{u}]$, and $[\mathrm{I}] \sim[\mathrm{i}]$ have different behavior from the sound correspondence of $[\mathrm{o}] \sim[\mathrm{a}]$. The sound $[\mathrm{e}] \sim[\varepsilon],[\mathrm{U}] \sim[\mathrm{u}]$, and $[\mathrm{I}] \sim[\mathrm{i}]$ cannot consistently appear in area A. Although in nature, people in area A prefer to use [lanit], for example; however, some other use [layIt]. It can be infer that due to some factors, maybe like language contact and modernization, sound [I] and [i] and other allophones are extensively used by the speakers in the area, meanwhile [0] [a] has higher degree of survivability.

\section{The Historical Aspect of the Variations}

People who migrated to Pringsewu regency came from different area in Java. The following table is the recap of profile of Observation Location (OL) or the Javanese village. It consist of name of village, origin and the first year of inhabiting the village. Due to incomplete documentation in village administration, some data are not clear in mentioning in which part of areas or at least city/ regency they were from.

\begin{tabular}{|l|l|l|l|}
\hline Area & OL & Origin & Year of Inhabiting \\
\hline \multirow{3}{*}{ A } & Wonodadi & Cilacap, Gombong, Karanganyar & 1907 \\
\cline { 2 - 4 } & Ambarawa & Kebumen & 1933 \\
\cline { 2 - 4 } & Bumiarum & Kebumen & 1929 \\
\cline { 2 - 4 } & Pamenang & Kebumen & $1950 \mathrm{~s}$ \\
\hline
\end{tabular}




\begin{tabular}{|l|l|l|l|}
\hline \multirow{4}{*}{ B } & Candiretno & Kroya & 1932 \\
\cline { 2 - 4 } & Banyuwangi & Ambarawa Pringsewu, and Java & 1952 \\
\hline & Gadingrejo Timur & Purworejo & 1907 \\
\cline { 2 - 4 } & Srikaton & East Java & $1930 \mathrm{~s}$ \\
\cline { 2 - 4 } & Totokarto & West Java, East Java, Yogyakarta & 1955 \\
\cline { 2 - 4 } & Pandansari & Central Java, East Java & 1941 \\
\cline { 2 - 4 } & Mataram & Sleman dan Kebumen & 1921 \\
\cline { 2 - 4 } & Wates & Purworejo dan Kebumen & 1919 \\
\cline { 2 - 4 } & Keputran & Java & 1954 \\
\cline { 2 - 4 } & Waluyojati & Java & $1950 \mathrm{~s}$ \\
\cline { 2 - 4 } & Kresnomulyo & East Java, Central Java & 1939 \\
\cline { 2 - 4 } & Pujiharjo & Java Central & 1962 \\
\cline { 2 - 4 } & Giritunggal & Java & 1955 \\
\cline { 2 - 4 } & Margosari & Java & . \\
\hline
\end{tabular}

Table 4. Origin Area of Javanese Village in Pringsewu and Their Year of Arrival

What makes Area A different from Area B in this research is the language behavior in both areas. Area A consists of villages whose origins were from Kebumen, Cilacap, Gombong, Karanganyar and Purworejo. Wonodadi village is the oldest Javanese village as it is not far from the center of first program of Kolonisasi Gedongtataan. The origin area in Area $\mathrm{A}$ is the area in Central Java especially in the southern and western part. Those are the areas where Javanese language with Banyumas dialect exist. Banyumas Javanese is also called "Ngapak" accent, a unique accent that is different from standard Javanese, spoken in the area of Banyumas, Wonosobo and Tegal and occurred because the Javanese developed far from the center of power (Kumparan, 2017) which is Yogyakarta Sultanate and Surakarta Sunanate.

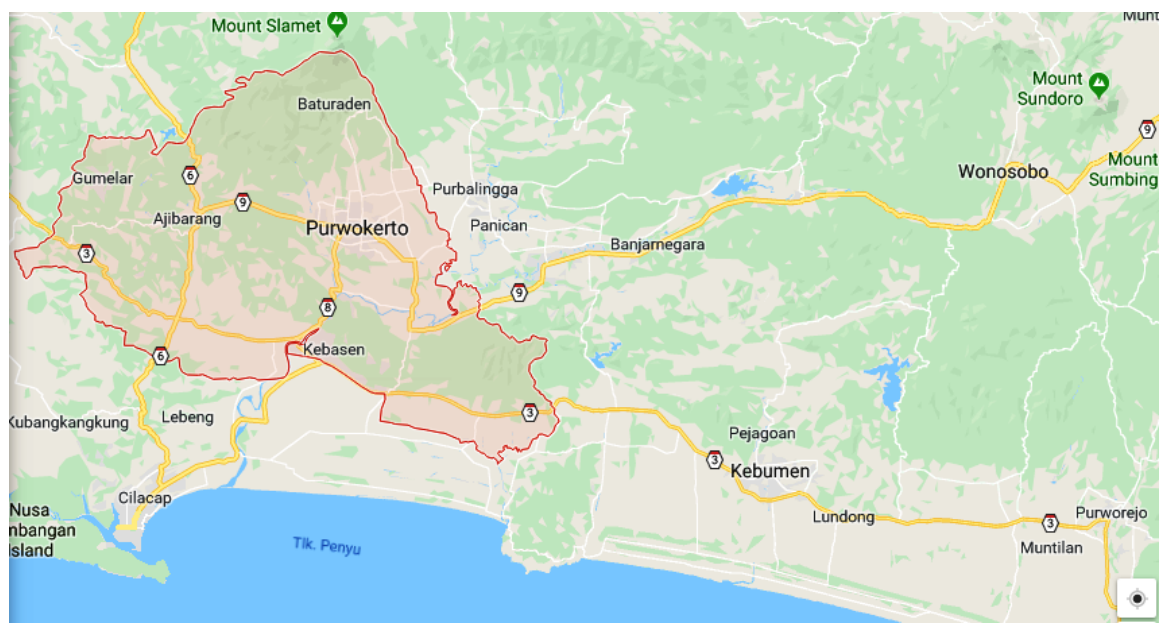

Picture 2. Map of Banyumas Regency

According to the map, the area bordered with red line is the area of Banyumas regency. This regency is close to the area of Kebumen as well as Cilacap where Banyumas Javanese dialect is spoken widely. Paryono (2011) explained that Banyumas Javanese is unique in pronouncing certain vowel [a], [i], and [u] sounds in the open syllable. Banyumas Javanese uses [a] sound meanwhile Standard Javanese uses [0] sound, [i] sound in Banyumas Javanese corresponds to $[\mathrm{I}]$ sound in Standard Javanese and $[\mathrm{u}]$ sound in Banyumas Javanese corresponds to $[\mathrm{U}]$ sound in standard Javanese. This accent is resulted from the culture contact to the neighboring culture, Sundanese, since Majapahit era (Poedjosoedarmo, 1982: 5 in Paryono, 2011). Looking at the first migration of speakers of Banyumas dialect, in can be concluded that Banyumas dialect or Ngapak accent has been exists in Lampung for about $20-110$ years. During this period, some features has partially changed like the vowel sounds 
mentioned earlier, but one feature of vowel sound that still exists until now is the correspondence [0] [a] along with some lexical variations occurred in the areas.

Mataram and Wates village were originally inhabited by people coming from Kebumen as well around 1919-1921. It was predicted that in the early period of migration to Lampung, the people were still using Banyumas dialects. However, due to the migration of people who speak standard Javanese in this area, people from Kebumen descendant did intense language contact and finally prefer to use standard Javanese for most of them. Furthermore, Wates area is crossed by provincial road so that there are more intense contacts to many ethnic groups in Lampung province.

Area $B$ in Pringsewu can be said as non-Banyumas dialect. It cannot be directly concluded that Area $B$ is the standard Javanese because the origin areas were not specific and too wide, for example the people just mentioned that their ancestor is from Central Java, East Java or Yogyakarta. It means that there are many varieties may appear here; however, it cannot be identified in this research. Mostly, people in Area B speak in the phonological pattern of Standard Javanese like using [I], [U] in last and open syllable. It might be an alternative to call this variety as Pringsewu Javanese. Therefore, it is still in grey area to decide that non-Banyumas pattern in this area as Standard Javanese.

\section{Conclusion}

Javanese varieties in Pringsewu and Lampung province can be at least classified into two, which are Javanese variety reflecting Banyumas dialect and Javanese variety that may reflect Standard Javanese. These varieties can be seen in some identical lexicon as well as some patterns of sound correspondence; however, some sound correspondences that exist in the origin area are fading, resulting in two choices: Banyumas dialect and Standard Javanese. The changes occurred due to language choice of the speaker due to contacts. The existence of Javanese varieties in Pringsewu portrayed to this dialectology study shows that Javanese language is still fluently spoken in daily basis. However, although changing slowly within certain time frame, the maintenance of the language should be the concern of the speakers themselves as technology and modernization is continuously developing resulting in changes in language preference.

Further direction for this research lies on the investigation of wider areas with more Observation Location as well as the phonological and morphological aspects to analyze. Segmenting the informants based on the age can also be alternative to see how far these two generation maintaining Javanese in their daily conversation.

\section{References}

Ayatrohaedi. 2002. Pedoman Penelitian Dialektologi. Jakarta: Pusat Bahasa Departemen Pendidikan Nasional.

BPS Pringsewu. 2015. Pringsewu dalam Angka 2015. Retrieved on November 132015 at www.pringsewuka.bps.go.id

Chambers, JK and Peter Trudgill. 2004. Dialectology Second Edition. Cambridge: Cambridge University Press.

Ethnologue. Ethnologue Language of the World. 2018. Retrieved on January 12018 at https://www.ethnologue.com/langauge/jav

Kementerian Pendidikan Nasional. 2013. Penelitian Kekerabatan dan Pemetaan Bahasa di Indonesia, Kuesioner Kosakata Dasar dan Kata Budaya Dasar. 
Kumparan. 2017. Asal-Usul Bahasa Ngapak Banyumasan yang Ceriakan Dunia. Retrieved on December 25 at https://kumparan.com/@kumparannews/asal-usul-bahasa-ngapakbanyumasan-yang-ceriakan-dunia

Lauder, Multamia RMT. 2007. Sekilas Mengenai Pemetaan Bahasa. Jakarta Timur: Akbar Media Aksara.

Nerbonne, John and Kretzchmar, William. 2003. Introducing Computational Technique in Dialectometry. Computer and the Humanities. Vol 37 (3), pp 245-255.

Paryono, Yani. 2011. Keunikan Bahasa Jawa Dialek Banyumas sebagai Cerminan Identitas Masyarakat Banyumas. Presented at Kongres Bahasa Jawa 5. Retrieved on December 142018 at https://ki-demang.com/kbj5/index.php/makalah-pengombyong/1203-21keunikan-bahasa-jawa-dialek-banyumas-sebagai-cerminan-identitas-masyarakatbanyumas/

Wedhawati. 2006. Tata Bahasa Jawa Mutakhir. Yogyakarta: Kanisius.

Zawarnis, Yulfi. 2009. Variasi Dialektal Bahasa Jawa di Lampung. Unpublished materials: Universitas Indonesia. 